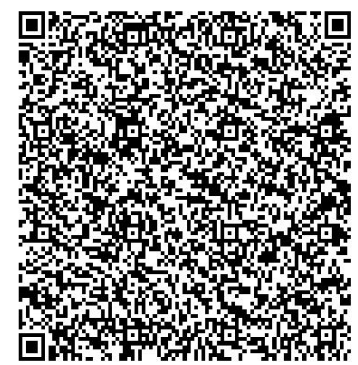

\title{
HOTEL INDUSTRY STRATEGIES FOR ENTREPRENEURSHIP
}

Jyotirmoy Ghosh* \& G. Anjaneyaswamy**

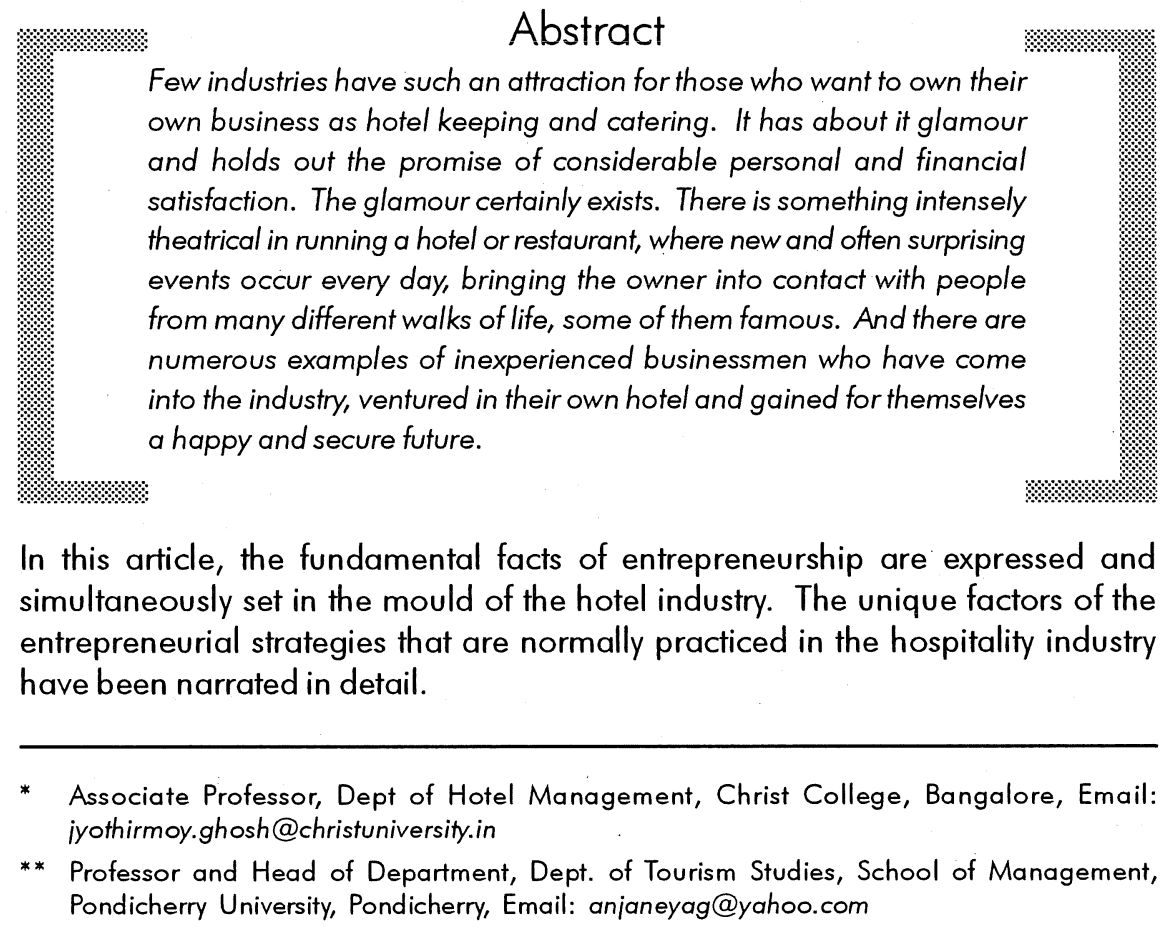


In the fundamental sense of the term entrepreneurship, is the creation of new business. The activities include opportunity recognition or creation, assembling resources to pursue the opportunity, and managing activities that bring a venture into existence. These ventures can be complete start - ups, while other ventures are pursued within an existing organization. One of the pioneering expert on entrepreneurship, Arnold Cooper states "Entrepreneurial Ventures, whether independent or within established corporations, might be viewed as experiments. They test to determine the size of particular markets or whether particular technologies or ways of competing are promising. They have good internal communication and enormous commitment from their key people." It would be interesting to study a few more pioneering definitions of entrepreneurship. The earliest one was perhaps by the French Economist J.B. Say who stated during 1800, "The Entrepreneur, shifts economic resources out of an area of lower and into an area of higher productivity and greater yield." Say's definition expresses the achievement of the entrepreneurs but does not specify who these entrepreneurs are and how they achieve their feat.

Joseph Schumpeter of the Austrian School of Economics, stated during 1950 "An entrepreneur is a person who is willing and able to convert a new idea or invention into a successful innovation." According to Schumpeter "Entrepreneurship forces creative destruction across the market and industries, simultaneously creating new products and business models. In this way creative destruction is largely responsible for the dynamism of industries and long - run economic growth."

According to Frank H. Knight during 1967, and Peter Drucker during 1970, entrepreneurship is about taking risk. The behaviour of the entrepreneur reflects a kind of person willing to put his or her career and financial security on the line and take risks in the name of an idea, spending much time as well as capital on an uncertain venture.

Professors Howard Stevenson and Jeffrey Timmons shared their views, as "The entrepreneur is someone who acts with ambition beyond that supportable by the resources currently, under his control, in relentless pursuit of opportunity." So according to them entrepreneurship is the process of discovering, evaluating and explaining opportunities, which go on to modify themselves in the form of new business ventures.

Gifford Pinchot introduced the term "Intrapreneuring" for expressing corporate entrepreneurship. According to Pinchot entrepreneurs are innovators within an organization who do not follow the routine path. They act as mavericks, are extremely creative and apply their self motivation to create a new product or situation, that brings revolutionary success to the firm. 
When we examine the above mentioned definitions and also reflect on the other various definitions of entrepreneurship not mentioned, the prominent factor which is noticed is an aspect of innovation. Entrepreneurs innovate. Innovation is the specific instrument of entrepreneurship. It is the act that endows resources with a new capacity to create wealth. Innovation indeed, creates a resource. Peter F. Drucker in his immortal lines states "There is no such thing as a 'resource' until man finds a use for something in nature and thus endows it with economic value. Until then, every plant is a weed and mineral just another rock. Innovation cannot be separated from a firms' strategy or its competitive environment, which means that what we consider to be innovative is defined by the context. Innovations may be a recombination of old ideas or a unique approach that is perceived as new by the individuals involved. The development of electronic newspapers from around the world delivered to hotel guests on demand is an example of a recombination of the old idea of providing a copy of a local paper to each guest room. Innovation is the combination of both invention and commercialization. Developing a new product or process is not enough; the innovative firm must know how to convert an idea into a service or product that customer wants.

Let us discuss the business strategy normally applied by the new hotel venture entrepreneurs. A study of some of the new hotel ventures in India and abroad, have helped me to introduce the following business plan. The entrepreneur confronts the following strategic issues.

\section{What Type of Hotel Should I open}

The decision of the type of hotel to be opened will depend on the budget in hand, hotel business knowledge, the land available and resources available to do business. Accordingly, the entrepreneur may select a downtown, luxury hotel, a budget hotel, a resort or a motel.

\section{The Location and the Land Availability}

Land and location is of primary importance for hotel business. As Mohan Singh Oberoi the founder of the Oberoi Chain mentions "The success of a hotel is in the location, location and location." As on today, the major part of the capital for a hotel project is consumed in land and building alone.

The general considerations an entrepreneur should follow are :-

- Who will be my customer?

- Will I have the correct accessibility? 
- The competition that I have to face

- The History of the location and also that of the hotel units existing.

- Growth factor considerations

- City versus suburban location and its cost benefit ratio.

- Buying an existing hotel

- Buying a closed hotel

- Building a free standing hotel

- Leasing consideration

- Management contract considerations.

- Professional bodies to be consulted:

1) Real estate agencies

2) Small Business Administration

3) Department of commerce

4) Local chamber of commerce

5) Our lawyer, accountant, banker, insurance agent and hotel consultant.

\section{Should I Follow the Franchise Route}

Franchising is a way of life for companies, enhancing the sales of their product while spreading the fame of the company name. It is a good way for a person without special skills to be trained in every aspect of the hotel business. One must be certain to check all the facts closely. A knowledgeable attorney to be retained to give the entrepreneur constant advice and counsel one must be sure that he or she can adapt to the type of franchise one is intending to enter.

\section{How much Capital I Need and How will I Raise the Finance}

The type of hotel one desires to operate will determine the amount of capital one needs. However, the well-planned and well-financed hotel with ample reserve for 
expected expenses, as well as for those which are unexpected have a far greater choice of success than the ill equipped, shoestring operating, which force the owner to work 24 hours a day in order to show a profit. One's banker, lawyer and accountant are the people who will help one arrive at a realistic estimate of how much money one will need to borrow, to start out right.

\section{Hotel business finance should cover the following :-}

1) The building and interiors financial requirements.

2) The various hotel equipment finances covering.

- Kitchen equipment

- Laundry equipment

- Bar and Restaurant equipment

- Linen

- Furniture and fittings

- Front office equipment

- Engineering and maintenance accessories

- Air conditioning

- Generator back up

- Lighting and heating

- Housekeeping equipments (cleaning, gardening, pest control etc.)

3) Financing the hotel suppliers, food and beverage suppliers and other vendors.

4) Sources for capital - Bank, Financial Institutions \& Venture Capital, Personal contacts, Corporate Partnership, Investment groups.

5) Building a reserve and considerations on long term borrowing and short term borrowing.

6) Availability and arrangement of collateral security.

7) Balance sheet considerations and accounts monitoring. 


\section{Room Inventory Planning}

The different categories of rooms to be designed and their corresponding pricing are to be decided. The number of rooms for each category, that are available for sale are to be decided. Based on this, the total room division sale can be decided. Rooms division account for 70 to 80 percent of the total hotel revenue and thus the entrepreneur can treat this area as most lucrative.

\section{Planning of Menus for all Food \& Beverage Outlets}

The menu is the blueprint of a restaurant and has many functions. It attracts and intrigues the customer, it provides the entrepreneur with a guide for ordering, purchasing and estimating income, it determines the layout of the kitchen and the special equipment the owner will need, it sets the tone of the restaurant-formal, ethnic or any other type - which will help the entrepreneur furnish and decorate it appropriately.

A successful food and beverage outlet menu is no accident. It is a result of careful planning with many factors involved in making it a success. The experience of the entrepreneur / manager in establishing proper formulas, updating costs, controlling leftovers, merchandising the menu and careful purchasing, are all important ingredients for a successful menu. A menu is more than a piece of paper listing food. Its objective should be to sell food.

\section{Planning, Purchasing, Receiving and Storage of various hotel inventories}

Hotel industry needs a wide variety of inventories, covering all the departments' consumable commodities. Meticulous planning is required to decide the purchases, receiving style, and storage system of all these inventories. Among these, particularly important, are those dealing with food and beverage commodities as these have various degrees of perishability. Considerable attention is given towards cold storage, ventilation, storage bins and racks, weights and measures, hygiene and sanitation factors and a sound control system. The entrepreneur should realize opening and closing stock, purchases and sales are all integral part of business profitability and are also the main factors in a balance sheet. Thus, it is advisable for the entrepreneur to acquire professional knowledge or hire / outsource the professional experience in this regard. 


\section{Strategic Use of Equipment, Design, Décor, Sanitary and Safety for Business Success}

An entrepreneur should know and utilize the equipments in correct layout, ensure correct power consumption, follow safety measures to handle, increase output and minimize wastage and also showcase them as per their usage, for business promotion. Similarly the design and décor of rooms, outlets, banquets, public areas are not mere beautification but also marketing and selling facilitation tools. Proper use of sanitation and safety measures can not only save the entrepreneur from serious legal problems but also provide the much desired "Moment of Truth".

\section{Manpower Considerations}

Hotel industry is manpower intensive. The entrepreneur should realize he should be a champion man manager. He needs a team of skilled men to serve another group of men, the guests. So the challenge of man management emerge almost everywhere. Manpower planning and execution takes place with the salary, wages, insurance, and other staff funds considerations. Hotels are usually launched in phased manner that is for a 100 rooms hotel, first phase would probably include 25 rooms, followed by 25 rooms for three more phases. For every phase, the required staff for the four core hotel area as front office, food and beverage service, food and beverage production and housekeeping are to be selected and simultaneously, the other allied areas are to be staffed, as the stores accounts, security, engineering and maintenance and so on. The entrepreneur should have sound knowledge of the job descriptions, number of staff required for every post, their salary and wages, legal structures, the bonus insurance, labour laws regarding working hours, disciplinary action and different compensations. Sound personnel management foundations to be laid, based on a strong human resources development and training methods imparted at various levels continuously. Strategic manpower management can ensure efficiency and growth to the hotel.

\section{Building Up the Business}

An entrepreneur hotelier needs to establish long - term objectives and short-term aims. The objectives are concerned with the coherent development of the hotel so that its business potential can be fully realized over a reasonable span of time upto five years, say. The short - term aims are mainly concerned with ensuring that the hotel immediately trades profitably, that sales opportunities are maximized and costs contained. 
Because a hotel is a small, individually owned unit, it does not mean that long term objectives are unnecessary, although there are hotels that survive from year to year without any plans for development or expansion. Every entrepreneur needs to know where he is going and how he wants to develop but there are many who believe that further development is either impossible or unnecessary. Generally, this is a conscious decision. Most entrepreneurs, however, have definite ideas about the future of their venture. Some of these may be long - term, for example, the construction of extra rooms so that more customers or a different market can be attracted. Other ideas may be more short-term, for example to make sure that existing rooms have a much higher occupancy or the food and beverage outlets sell more covers. Marketing is concerned with long - term objectives while shortterm aims are generally achieved by sales promotion techniques.

A marketing plan will be the blueprint for the business development of the hotel and will show what kind of customers the hotel can best attract, what their needs are and how the hotel is going to satisfy those needs over a specific period of time. In a large hotel, the plan would be a sophisticated document but for a small establishment this need not be the case. However detailed and lengthy it is, it must answer two strategic questions:

1) Has the potential of the business been realized as the business stands now?

2) Once the present potential has been realized, how can the business expand in the future?

\section{Strategic Use of the Internet and E-commerce}

Entrepreneurs should realize the hotel industry should survive in an age of expanding worldwide communication. The internet is a major part of the Information Revolution. According to Peter Drucker, "The explosive emergence of the internet as a major, perhaps eventually the major, worldwide distribution channel for goods, services, and, surprisingly, for managerial and professional jobs is profoundly changing economies, markets, and industry structures, products and services and their flow, consumer segmentation, consumer values, and consumer behavior, jobs and labor markets."

\section{Strategic Electronic Tourism Marketing}

Travel is the most successful commercial sector on the internet, bringing fundamental changes to both airlines and travel agencies. Airlines in particular were aggressive leaders in using the internet to bypass their product and service intermediaries, with 
the advent of electronic ticketing in 1995, airlines reduced distribution costs by combining their established national networks and brand awareness with direct internet sales. Traditional travel agencies began losing sales not only to airline sites but also to online agencies.

Hotel companies have also joined forces in e-commerce ventures to purchase supplies. For example, Marriott partnered with Hyatt to form Avendra. Intercontinental Hotels Group and Fairmount have also joined the venture.

Web bookings have put incredible pressure on prices in the lodging industry. Research at Cornell University has shown that heavy price discounting in hotels did not yield the desired boost in market share or occupancies. Internet intermediaries such as Hotels.com can be blamed for the reported losses in revenue, as consumers have learned that they can get a better price for a hotel room by going to the internet.

Another strategic approach to retain control over pricing and inventory has resulted in alliances among major competitors to create their own websites. One example is the Travel Web Consortium, led by Marriott, Hilton and Hyatt.

\section{The Ultimate Bottom Line - Profitability}

When a hotel venture fails; the entrepreneur blames everything and everyone - the equipment, location, employees, bank, even the government, but never is it his / her fault. The truth is that many businesses fail because the owner / entrepreneur never took the time to study hotel management fundamentals, had no knowledge of food preparation, was not able to communicate with people, had no business knowledge, did not understand what profit really is, did not stay abreast of the industry, and did not really watch the business.

The most common reason for the failure of entrepreneurial venture is lack of management skill. This is sometimes demonstrated by a poor management strategy, inappropriate vision, or an inability to manage finances effectively. Many new venture fail because of a lack of capitalization. Other factors that can lead to failure are associated with the service itself, such as poor timing. Even if a venture has excellent management, sufficient capitalization, and a good service, it can still fail if market conditions are not favourable. Thus an appropriate hotel venture business strategy combined with a favourable environment can produce profitability.

Profit is one thing the entrepreneur cannot do without, in any business. To make a profit, one must always be on the alert by watching every angle of his / her business, 
how the rooms are sold, how food is prepared, how it is stored, what are the purchasing procedures, how food and beverage sales are progressing, the employees attitudes, their work habits plus the customers' acceptance of products and services. The entrepreneur can be successful if he / she challenges and train himself / herself to be profit conscious.

Profit is the only thing that will enable the entrepreneur to survive, to expand, to give a raise to the employees and also to him. Profit is the lifeblood, which will make the business survive and grow.

\section{Conclusion}

L.E. Shefsky expresses the true spirit of entrepreneurs beautifully in his work "Entrepreneurs Are Made Not Born".

"Would be entrepreneurs live in a sea of dreams. Their destinations are private islands - places to build, create, and transform their particular dreams into reality. Being an entrepreneur entails envisioning your island, and even more important, it means getting in the boat and rowing to your island. Some leave the shore and drift aimlessly in the shallow waters close to shore, while other paddle furiously and get nowhere, because they don't know how to paddle or steer. Worst of all are those who remain on the shore of the mainland, afraid to get in the boat. Yet all those dreamers may one day be entrepreneurs, if they can marshal the resources external and internal - needed to transform their dreams into reality."

\section{References}

- Mc. Carthy A.M. and Nicholls - Nixon C.L. "Fresh start : Arnold Cooper on entrepreneurship and wealth creation," Academy of Management executive, 15, no.1 (February 2001).

- Min S.J. "Made Not Born," entrepreneur of the year Magazine, fall 1999, 80.

- Quest Miles "How to buy your own Hotel" (1979) Northwood Publications Ltd London.

- Rich John "Restaurant Finance" (1975) Lebhar - Friedman Books. New York.

- Drucker Peter. F. "Innovation and entrepreneurship - practice and principles". (1985) Harper and Row Publishers, New York.

- Shelf Sky L.E. "Entrepreneurs are made not born" (1994) Mc Graw - Hill. New York.

- Rainsford P. and Bangs D. "The Restaurant Planning guide: Starting and Managing a Successful Restaurant" (1992) Upstart Publishing Company. Dover. 